\title{
HSP90B2P wt Allele
}

National Cancer Institute

\section{Source}

National Cancer Institute. HSP90B2P wt Allele. NCI Thesaurus. Code C116983.

Human HSP90B2P wild-type allele is located in the vicinity of $15 q 26.3$ and is approximately $3 \mathrm{~kb}$ in length. This allele, which may encode putative endoplasmin-like protein, may be involved in protein folding. 